\title{
A TRANSDISCIPLINARY PERSPECTIVE OF THE CURRENT CRISIS SITUATION IN THE WORLD
}

\author{
Paulo Nuno Martins ${ }^{1}$ \\ ${ }^{1}$ Researcher, \\ $\mathrm{PhD}$ History and Philosophy of Science (FCT-UNL), \\ Centre Internationale de Recherche et d'Études Transdisciplinaire, \\ CIRET,Paris, \\ Transdisciplinary Center for Consciousness Studies, CTEC, University \\ Fernando Pessoa of Oporto, Portugal, \\ Interuniversity Center for History of Science and Technology, \\ CIUHCT, New University of Lisbon, Portugal,
}

Article DOI: https://doi.org/10.36713/epra4404

\begin{abstract}
This short communication aims to be a contribution on the transdisciplinary perspective of the relationship between spirituality and the current global crisis situation due to Covid-19.

KEYWORDS: Current global crisis situation, Covid-19 combat modes, Indian spirituality, A transdisciplinary perspective of the current crisis situation.
\end{abstract}

\section{INTRODUCTION}

The coronavirus pandemic (abbreviated Covid-19) has brought about the changes that "cyclically" societies have to face, leading to the emergence of new paradigms [1]. For example, nowadays some changes that are already taking place on the areas of Artificial Intelligence (with the use of algorithms to discover the mode of action of corona virus), new technologies with the use of the internet (for non-classroom teaching, teleworking, take-away) and telemedicine (for remote consultation) [2] that are a reflection of this need to readjust to the new demands of contemporary society.

\section{METHODS}

In this short communication on transdisciplinary perspective on the current crisis situation, I analyzed and selected the 12 most important items about this topic, based on the "impact factor" of the article and the book that might be useful to the reader who just wants to have an idea on this theme, but maintaining the scientific rigor of my research.

\section{RESULTS AND DISCUSSION}

In this section, I will present the results of my research on the current global public health situation due to Covid-19, describing the most relevant facts of my research work.

In medical terms, SARS-CoV-2 virus has circulated only in the animal kingdom, namely, through bat droppings, which are the food of pangolins. Thus, nowadays there is a hypothesis that pangolins are the hosts that transmit SARSCoV-2 from bats to humans. In fact, human beings, particularly the Chinese population, having ingested the pangolins have allowed this virus to "jump" into the human kingdom. Through the air, human beings have infected each other [3]. Currently, the pharmaceutical Gilead Sciences is studying some ways of combating the disease Covid-19 that is the infection caused by the genetic material of SARS-CoV-2 coronavirus. This could be performed through an antiviral called "Remdesivir", which prevents the virus from replicating itself. In fact, the virus (as if it were the "key") seeks to take over the entire cell (as if it were the "door lock") in order to multiply itself, although there is still no knowledge how to "close" the "door lock". Most positively, there are several kinds of vaccines under development 
against Covid-19, namely by the multinational Johnson\&Johnson, and some others companies in the area of Biotechnology, such as Moderna/NIH that has already started testing in humans [4].

On the other hand, even before the Covid19 appeared, many people in various parts of the planet were already suffering from hunger and war on a daily basis, as is the case with Sudan and Syria. In this regard, I want to highlight the interconnection between spirituality and health in a kind of "network of life" that could allow a global improvement of the living conditions of all human beings [5].

In fact, I want to refer some extraordinary human beings who have sought to alleviate the suffering of mankind. Some examples of these people have been Mother Teresa of Calcutta, or more recently Ammachi who has founded "Embracing the World", whose financial resources have allowed to minimize in a practical way the damage due to natural or human causes [6]. In this regard, I would like to emphasize the importance of Indian spirituality in contributing to the broader view of the current crisis situation in the world [7] and which is described by the statement " $L e$ 21ème siècle sera spirituel ou ne sera pas" assigned to André Malraux [8].

Meanwhile, the World Health Organization (WHO) has defended that community isolation and social contact should be avoided, as well as washing hands and put masks on the face, as the most effective ways to minimize the exponential advance of the Covid-19 (until an effective vaccine might be discovered by scientists) [9]. Thus, the minimization of the effects of Covid-19 has led the governments of the several countries to seek to balance between the protection of health and financial stability of people [10]. From a transdisciplinary point of view, the current crisis situation might be the result of some wrong actions of human beings over time, as it has already been referred to by Basarab Nicolescu, in relation to Anthropocene [11].

\section{CONCLUSION}

Finally, from my point of view, coronavirus pandemic could contribute to some changes in certain areas of human life in contemporary society, such as, health, economy and work, general relationships, where the key phrase will be "the interconnection of each species for the balance of life on Earth, highlighting the common good". For example, health should be the most precious asset to which all governments must give top priority (through free access to the National Health Service); economy should promote (whenever possible) telework, so that the worker might have more free time for the family; general relationships should promote selfawareness where personal well-being might be linked to the well-being of others human beings (through solidarity between countries, as proposed by the European joint project). All these topics are the essence of spirituality, which aims at a better quality of life for all human beings [12].

\section{REFERENCES}

1. P. Martins. "Fatima and the values of contemporary society: An essay", Icon of Faith. International Journal of Interdisciplinary Scientific Research, 11(6):37-40. 2020.

2. G. Polakovic, "USC experts explore new technologies to combat COVID-19". University of Southern California (USC) News. 2020.

3. J. Ziebuhr. "Coronaviruses", Advances in Virus Research, Vol.96. 2016.

4. C. Gordon, E. Tchesnokov et al. "The antiviral compound remdesivir potently inhibits RNAdependent RNA polymerase from Middle East respiratory syndrome coronavirus". J. Biol. Chem., 1-14. 2020; S. Knvul, K. Thomas. "Researchers Are Racing to Make a Coronavirus Vaccine. Will It Help?", The New York Times. 2020.

5. P. Martins. "History of Religion and Medicine: The Healing of Soul and Body". International Journal of Scientific Engineering and Science, 3(9):56-59. 2019; coronavirus". J. Biol. Chem., 1-14. 2020; F. Capra. The Web of Life. HarperCollins Publishers. 1997.

6. P. Martins. "A Gnose e a Espiritualidade no Bhagavad-Gita: Uma fonte de inspiração de Vida", III International Congress on Science of Religions on Religion, Ecology and Nature, Universidade Lusófona de Humanidades $e$ Tecnologia, 31 de Janeiro a 5 de Fevereiro 2020, Lisbon, Portugal. 2020.

7. M. Meera. "Answers for these Times". Mother Meera Foundation USA. Spring 2020.

8. A. Malraux. La condition humaine. Edition Gallimard. 2012.

9. World Health Organization (WHO). "Coronavirus disease (Covid-19) Pandemic". Situation Reports and Advice for Public. 2019.

10. R. Baldwin, Richard. Economics in Time of Covid-19. Centre for Economic Policy Research (CEPR) Press. 2020.

11. B. Nicolescu. "Science and Orthodox Christianity confronted with the New Barbarism - Panterrorism, Anthropocene and Transhumanism", International Conference on Orthodox Christianity and the Reassessment of Scientific Knowledge, 9-10 February 2018, Athens, Greece. 2018.

12. P. Martins. "História da Ciência, Psicologia Junguiana e Espiritualidade: uma visão transdisciplinar para a qualidade de vida", Religião, Espiritualidade e Qualidade de Vida, In: J. Brissos-Lino, B. Gonzalez (Org.), Edições Universitárias Lusófonas, 2: 59-65. 2020. 